\title{
Technology of Animal Feed Processing (Fermentation and Silage) in Bilah Hulu Village, Labuhan Batu Regency
}

\author{
Andhika Putra*, Ismail D, Najla Lubis \\ Faculty of Agriculture, University of Pembangunan Panca Budi
}

\begin{abstract}
The specific target in this activity was to introduce fermentation and silage methodology to improve the quality of animal feed to Mekar Baru stock farmers cooperatives in Labuhan Batu Regency. Seminars and discussions were conducted as parts of the community service which then followed up by direct practice about animal feed fermentation and silage. The results of the mentioned activities included seminars, discussion, and fodder. In conclusion, the technology of animal feed processing is in a high favorand needed by people in the village, especially beef cattle farmers whose livestock was only given green animal feed all this time.
\end{abstract}

Keywords: Animal Feed, Fermentation, Silage, Beef Cattle

\begin{abstract}
Abstrak. Tujuan jangka panjang pengabdian ini adalah untuk memberikan informasi tentang teknologi fermentasi dan silase untuk meningkatkan nilai gizi pakan ternak di kelompok tani ternak Mekar Baru di kecamatan Labuhan Batu. Metode pelaksanaan pengabdian ini adalah dengan ceramah dan diskusi serta kemudian dilaksanakan praktek lamgsung bersama dengan anggota kelompok tani ternak tentang pembuatan fermestasi dan silase pakan ternak. Hasil pelaksanaan pengabdian ini ceramah, diskusi serta pembuatan fermentasi dan silase pakan ternak sapi potong. Kesimpulan pengabdian ini adalah teknologi pengolahan pakan sangat diminati dan dibutuhkan oleh masyarakat desa kampung dalam khususnya peternak sapi potong dimana selama ini ternak mereka hanya diberikan pakan hijauan saja oleh peternak.
\end{abstract}

Kata kunci : Pakan Ternak, Fermentasi, Silase, Sapi Potong

Received 4 November 2017 | Revised 15 January 2018 | Accepted 15 February 2018

\footnotetext{
*Corresponding author at: Jalan. Gatot Subroto KM 4.5 Medan 20122, Indonesia

E-mail address: andhikaputra@ dosen.apncabudi.ac.id ${ }^{1}$ 


\section{Introduction}

Mekar Baru, one of the livestock farming groups in Kampung Dalam Village, Bilah Hulu Sub-District, Labuhan Batu Regency, runs in ruminants farming especially cattle. At first, the group had 20 group members and 50 cows. A partial system is used in taking care of the cattle which means that cows stay in different byres. In other words, the cattle raising activity is not done together. Most cattle are raised in a semi-intensive way which means that the cattle stay in byre at night and shepherded in the morning to the afternoon around the farming area. In contrast, others have raised cattle intensively which means that the cattle stay in the byres the whole day and food is brought to them.

Green animal feed available in the area is grass or plants managed by an oil palm plantation and rice straw as the waste from rice plantation. Rice straw is only available in big quantity during rice harvesting season whereas greens from the plantation can be given to livestock as long as the greens are not fertilized. The total amount of feed is huge and can be used to feed livestock continuously with an appropriate technology.

The fluctuating availability of greens causes problems to stocks farmers especially in Kampung Dalam Village, Bilah Hulu Sub-District, Labuhan Batu Regency. Therefore, an appropriate technology is required to process agricultural waste and greens to be utilized continuously and to improve the quality of animal feed. One technology used is silage. Silage is afermentation process by lactic acid producing bacterias in certain water level.

Following were the problems faced by people in Kampung Dalam Village, Bilah Hulu Sub-District:

1. The availability of animal feed all the time.

2. Low nutrition quality of greens animal feed.

3. Special training about the usage of greens and the technology to process them has never been conducted yet.

4. Low motivation to utilize rice straw or plantation waste.

\section{Method}

\subsection{Approach Methods}

The approach methods used in this community service were as follow:

a. Seminar and discussion. Materials for the seminar and training were given to the participants. After the seminar ended, discussion followed. Finally, direct practice to produce fodder was conducted. 
Materials for the seminar were:

- Information about food source for livestock

- The utilization of rice straw, a byproduct, as animal feed

- The increase of nutrition in animal feed

- The technology of animal feed processing

b. Direct practice of animal feed processing technology in which silage was made. Tools and materials were provided by the participants.

c. Participants were expected to be enthusiastic about participating in the programs held by LPPM and UNPAB community service team after the seminar and socialization were conducted.

\subsection{Work Procedure}

Working procedure was made to support the realization of the solution offered. First, an observation was done by doing an interview to analyze problems and effective solutions to the problems. Next, coordination with related stakeholders (related institution, village apparatus, and livestock groups) was made in order to hold a workshop or training about animal feed processing (animal feed fermentation and silage) for the stock farmers, especially for Mekar Baru group. Finally, evaluation was performed to whole activities conducted.

\subsection{Evaluation Description of the Community Service Implementation}

Evaluation of the community service implementation was conducted after the program was completed. The evaluation includes the benefits and the application of training and socialization about animal feed processing.

\section{Results and Discussion}

The program was conducted on 20 April 2017 and post-observation was done on 20 May 2017. The results found were as follow:

1. The stock farmers were seen to ferment rice straw for animal feed.

2. Food source for livestock was easy to get because farmers can use rice plantation waste (rice straw) to provide animal feed.

3. Farmers understood how to increase the quality of animal feed by making fodder or silage through fermentation of plantation waste material.

4. Stock farmers have started to socialize animal feed processing technology to other farmers in the adjacent village.

Through the community service program in Kampung Dalam Village, Bilah Hulu Sub-District, Labuhan Batu Regency on 20 April 2017 with the theme: "Animal Feed Processing Technology 
(Fermentation and Silage) in Desa Bilah Hulu, Kabupaten Labuhan Batu" and the post-program observation was done on 20 May 2017 can be seen to have a number of positive changes based on the explanation above.

Waste materials as byproducts from the plantation in the area were sufficient to support the development of ruminants farmings (beef cattle farm). This is because the area where the community service was conducted is adjacent to private owned plantations and archipelago plantation company (PTPN). Furthermore, the area has a lot of rice fields. Therefore, there is a huge potential to produce waste such as rice straw, midrib straw from palm foliage and grass grow around the farm.

Such potential is very useful in developing cattle business, especially in the beef cattle business in Mekar Baru farming group by using animal feed processing technology,such as the fermentation and silage technology. These two technologies can be applied to improve the quality of animal feed made either from farming waste or waste from the plant itself.

The greens or plants used to determine the silage formed where silage from forage and legumes give a different lactic acid. Legumes silage give a higher butyric acid content than what forage silage does. Then, the buffering system capacity causes drop in $\mathrm{pH}$, but legumes silage does not drop as fast as forage silage does. Budiman added Gliricidia leaves in the process of making rice straw silage; A (mark put on Giricidia leaves), B (10\% from the straw weight), C (20\% from the straw weight) and $\mathrm{D}$ (30\% from the straw weight) [1]. The data above shows $\mathrm{pH}$ increase with the addition of Gliricidia leaves in the silage making process. The rise in $\mathrm{pH}$ might be caused by high buffering capacity in legumes than in grass.

According to Knicky, buffering capacity can increase during ensilation which is caused by the high production of organic acid like nitric and sulphate acid which hinder $\mathrm{pH}$ to drop[2]. High protein content in silage produces silage with high $\mathrm{pH}$. This is because base materials with high protein hinder $\mathrm{pH}$ to drop by producing buffering capacity.

\subsection{Pre-ensilation Treatment}

Materials condition prior to ensilation affect the quality of silage produced, especially withering process. Cavallarian and colleagues(2005) suggested to reduce water content in legumes to $320 \mathrm{~g} / \mathrm{Kg}$ through machine heating, hence butyric acid fermentation and protein reshuffle can be pressed [3].

Dry content in materials influences competitive properties of LAB during silage fermentation. Lactic acid bacteria usually used in ensilation belongs to Lactobacillus, Pedioccus, Leuconostoc, Enterococcus, Lactococcus and Streptococcus genomes. Generally, they are mesophilic, an organism that can grow in the temperature of $5-50^{\circ} \mathrm{C}$, and able to reduce $\mathrm{pH}$ to 4.5 depending on 
the types of bacteria and the greens used. Lactic acid bacteria are divided into 2 classifications: homofermentative and heterofermentative LAB [4].

\subsection{Duration of fermentation}

The fermentation period is very important to determine silage harvest. This is, indeed, when the criteria of good quality silage have been fulfilled. An inoculum from buffalo's rumen in rice straw incubated anaerobically for 2 weeks and produced a good quality silage that fulfilled all the criteria [5].

The fermentation process can increase the availability of substances, such as protein and metabolic energy. Moreover, the process leads to the ability to break down complex matter to be simpler [6]. Fermentation is a reshuffling process of structure physically, chemically and biologically; thus, matters of a complex structure can be simpler. As a result, digestibility of livestock is more efficient [7]. Silage is a feed of fresh greens preserved by anaerobic fermentation in high water content (40 to $70 \%$ ). Therefore, the output can be stored without damaging the substances and nutrition in the food. Fermentation process which becomes significant is the process of using lactic acid producing microbe known as LAB. The fermentation plays some roles in farming industries such as: (1) Feed preservation either for greens or seeds;(2) improving livestock digestion system through the role of LAB as probiotic; and (3) have roles in post-harvest or preservation technology and increasing the quality of dairy and farm products as well as waste recycling.

Lactic acid produced with inoculum added gives such a huge difference than without inoculum added. R0 (without inoculum added), R1 (2\% of inoculum), R2 (3\% of inoculum), and R3 (4\% of inoculum). VFA concentration, which includes acetic acid, propionate, and butyrate, is a reflection of inefficient fermentation or secunder fermentation has taken place. The amount of $\mathrm{LAB}$ at the beginning of fermentation is an important factor to determine the silage obtained [8]. The population of lactic acid bacterias should be in a great amount for an effective fermentation. Therefore, there is a lot of research aiming to get a good dosage.

The right addition of LAB results in a good quality of silage. LAB is found naturally in greens but in a different amount. Therefore, the addition of LAB in silage making is necessary. The concept of adding inoculant bacteria is to trigger the growth of LAB homofermentative which does not produce lactic acid instantly to reduce silage $\mathrm{pH}$ [9].

The mechanism of lactic acid production according to Stefani and colleagues is in 4 stages [4]. The first step is an aerobic phase which normally takes 2 hours when oxygen in the atmosphere and between plants particles is reduced. Oxygen between plants' particles is used by the plants, aerobic microorganism, and aerobic facultative, such as yeast and Enterobacteriaceae for 
breathing. The second phase is fermentation. This phase is the beginning phase of anaerobic reaction which takes place for several days to weeks depends on the composition and condition of silage. If silage process goes perfect, then LAB is developed successfully. Lactic acid bacteria in this phase will become a predominant bacteria with silage $\mathrm{pH}$ of 3.8 to 5 . The third phase is stabilization phase which is a follow-up from the second phase. Finally, the fourth phase is a feed-out or aerobic phase. An opened silo causes silage to have direct contact with the environment and causes the aerobic process to happen. The same thing happens if there is a leakage in the silo which might lead to bad-quality to damaged silage. Silage quality depends on the speed of lactic acid formed in the fermentation process. That is the reason why there are several additives for silage.

The addition of LAB in King Grass can increase the quality of silage fermentation which is shown by a significantly decreased $\mathrm{pH}$ value and concentration of $\mathrm{N}^{-\mathrm{NH}_{3}}$. In addition, the concentration of lactic acid from the Fleigh value that increases significantly compared to the controlled silage. The addition of $3 \%(\mathrm{v} / \mathrm{b})$ LAB produces a better quality fermentation compared to 2 or $4 \%$ content [10].

\section{Conclusion}

Socialization and training held shows positive changes in the management of feeding beef cattle, especially in Mekar Baru livestock farming group. Technology shared and used in the farming group aligns with government policy regarding beef self-sufficiency.

\section{References}

[1] Budiman. 2007. Pengaruh berbagai kombinasi jerami padi dengan daun gamal terhadap kualitas silase. Buletin Nutrisi dan Makanan ternak 6(1):47-53.

[2] Knicky, M. 2005. Possibilites to improve silage conservation. Effect of crop, ensiling tecnology and additive. Faculty of veterinary medicine andanimal science. Uppsa.

[3] Cavallarian, L., S. Antoniazzi, and E. Tobacco. 2005. Effect of wilting and mechanical conditioning on proteolysis in sainfoin wilted herbage and silage. Journal of the Science of Food and Agriculture 85: 831-838.

[4] Stefani, J. W. H., F. Driehuis, J. C. Gottschal, and S. F. Spoelstra. 2010. Silage fermentation processes and their manipulation: 6-33. Electronic conference on tropical silage. Food Agriculture Organization.

[5] Thalib, A., J. Bestary., Y. Widyawati, and D. Suherman.2000. Pengaruh perlakuan silase jerami padi dengan mikrobia rumen kerbau terhadap daya cerna dan ekosistem rumen sapi. Jurnal Ilmu Ternak dan Veteriner 5(1): 276-281.

[6] Kompiang, L.P., J. Dharma, T. Purwadaria, A. Sinurat, and Supriyati. 1994. Protein enrichment: Study cassava enrichment melalui bioproses biologi untuk ternak monogastrik. Kumpulan Hasil-Hasil Penelitian APBN Tahun Anggaran 1993/1994. Balai Penelitian Ternak. Ciawi, Bogor. 
[7] Hanafi, N.D. 2008. Teknologi Pengawetan Pakan Ternak. Departemen Peternakan, Fakultas Pertanian, Universitas Sumatera Utara. Medan.

[8] Santoso, B., B. T. Hariadi, H. Manik, dan H. Abubakar. 2008. Kualitas rumput unggul tropika hasil ensilase dengan bakteri asam laktat dari ekstrak rumput terfermentasi. Media peternakan32(2):137-144.

[9] Ohmomo, S., O. Tanaka, H. K. Kitamoto, and Y. Cai. 2002. Silage and microbial performance, old story but new problem. JARQ 36 (2):59-71.

[10] Antaribaba, M. A., N. K. Tero, B. T. Hariadi, and B. Santoso. 2009. Pengaruh taraf inokulum bakteri asam laktat dari ekstrak rumput terfermentasi terhadap kualitas fermentasi silase rumput raja. Jurnal Ilmu Ternak dan Veteriner 14(4):278-283. 